\title{
STUDIES ON NEOTROPICAL POMPILIDAE (HYMENOPTERA). IX. THE GENERA OF AUPLOPODINI*
}

\author{
By Howard E. Evans \\ Museum of Comparative Zoology, Harvard University, \\ Cambridge, Mass. 02 I38, U.S.A. ${ }^{1}$
}

The posthumous paper of Hermann Haupt on the classification of the Macromerinae (Haupt, I959) is an unworthy memorial to its author and an unfortunate step backward in the systematics of spider wasps. Working from very little material and a lack of awareness of research in other parts of the world, Haupt erected I2 new genera, few if any of which are likely to stand the test of time. Two of them actually belong in the subfamily Pompilinae, as synonyms of Priochilus Banks (Evans, I966), while others will fall in the Pepsinae in most classifications (Compsagenia, Anapriocnemis). His inclusion of such diverse elements in the Macromerinae suggests the difficulty in defining the group, which I would rank as a rather weakly characterized tribe of Pepsinae and call the Auplopodini, after the first genus to be used in a suprageneric sense, Pseudagenia, now properly called Auplopus.

I am not in a position to straighten out all the confusion caused by Haupt's paper, but I wish to consider seven genera which he described from the neotropics, all of which can be promptly relegated to synonymy. There are, however, several remarkable new genera and subgenera of this tribe in South America, which both Haupt and Banks (1946) were unaware of, and I shall use this opportunity to describe these taxa and to present a revised key to neotropical Auplopodini.

I am much indebted to Professor J. O. Hüsing, of the Zoologisches Institut, Halle, for permitting me to borrow some of the specimens that Haupt studied, including several types.

\section{Pseudageniella Haupt}

Pseudageniella Haupt, 1959, pp. 23, 46 (type-species: Pompilus rusticus Fabricius, 1804, monotypic and by designation).

*Published with the aid of a grant from the Museum of Comparative Zoology.

${ }^{1}$ Present address: Dept. of Entomology and Zoology, Colorado State Univ., Fort Collins, Colo. 80521.

Manuscript received by the editor, June 7, 1973. 
I have not seen the type of rusticus, but the specimens that Haupt had before him agree perfectly with the type of Priophanes insolens Banks, 1946, and they are from the same locality. This is a wellmarked and evidently common species, and these specimens agree well with Fabricius' description. I therefore do not hesitate to consider insolens Banks a synonym of rustica Fabricius (new synonymy). Townes ( I957) places insolens in Ageniella, subgenus Ameragenia, an assignment with which I concur; thus $P$ seudageniella Haupt falls as a synonym of Ameragenia Banks, I945 (new synonymy). In his key, Haupt states that this genus is from the Nearctic region, an obvious error, since he states on p. 46 that his material is from Brazil.

\section{Allageniella Haupt}

Allageniella Haupt, 1959, pp. 23, 46 (type-species: Allageniella obsoleta Haupt, 1959, monotypic and by designation).

Haupt separated this genus from the preceding on exceedingly minor characters, and in fact his obsoleta and his specimens of rustica differ primarily in size and coloration. I have compared the type specimen of obsoleta Haupt with that of Priophanes plagosa Banks, 1946, and found them to be conspecific; again, both are from the same locality. Townes ( 1957) also places plagrosa in Ageniella, subgenus Ameragenia. Thus Allageniella is to be regarded as a synonym of Ameragenia Banks, obsoleta a synonym of plagosa Banks (new synonymies).

\section{Brachyagenia Haupt}

Brachyagenia Haupt, 1959, pp. 25, 59 (type-species: Brachyagenia nigra Haupt, 1959, monotypic and by designation).

By comparison of type specimens, $B$. nigra is to be regarded as a synonym of Ameragenia thione Banks, I946;Brachyagenia thus represents still another synonym of Ameragenia Banks (both new synonymies).

\section{Parageniella Haupt}

Parageniella Haupt,1959, pp. 26, 61 (type-species: Priocnemis rufofemoratus Taschenberg, 1869, monotypic and by designation).

The type-species is a well-marked Argentinian form and I have little doubt that Haupt and Banks identified it correctly. Banks placed rufofemorata in Priophanes, but like most of Banks' South 
American Priophanes the species will run to Ameragenia in 'Townes' (1957) key. I would regard Parageniella as still another synonym of $A$ meragenia (new synonymy).

\section{Cosmagenia Haupt}

Cosmagenia Haupt, 1959, pp. 28, 63 (type-species: Agenia amabilis Taschenberg, 1869, by designation).

I have studied Haupt's material of amabilis and found it conspecific with Ageniella amoena Banks, 1946. Since Haupt presumably had access to Taschenberg's types, it seems safe to place amoena in the synonymy of amabilis (new synonymy). This species is properly placed in the genus Priocnemella Banks, 1925, and Cosmagenia can thus be relegated to the synonymy of that genus (new synonymy).

\section{Compsagenia Haupt}

Compsagenia Haupt, 1959, pp. 29, 66 (type-species: Compsagenia laevipes Haupt, 1959, monotypic and by designation).

Study of the type specimen of laevipes shows it to be conspecific with the type of Nannochilus obscurus Banks, 1946 (new synonymy). Townes (1957) has correctly placed Nannochilus in the synonymy of Minagenia Banks, 1934, and Compsagenia Haupt should now be added to the list (new synonymy). Since levipes Cresson, I869, also belongs to this genus, Haupt's laevipes is both a homonym and a synonym. Townes assigns Minagenia to the subfamily Ceropalinae, tribe Minageniini. I would assign it to the Pepsinae, but I do not pretend to understand how the genera should be grouped within that subfamily; at any rate Minagenia does not belong in the Auplopodini.

\section{Anapriocnemis Haupt}

Anapriocnemis Haupt, 1959, pp. 25-26, 60-61 (type-species: Pompilus flavipes Guerin, 1836, by designation).

$P$. Alavipes is a well known Chilean species which has been assigned by Townes ( I957) to the genus Priocnemis, subgenus Sphictostethus Kohl, along with the other two species assigned by Haupt to Anapriocnemis. Since the type of Sphictostethus has a brachypterous female, it might be argued that flavipes is not correctly assigned to that subgenus (though I would not so argue); in any case $A$ napriocnemis may be placed in the synonymy of Priocnemis Schiöde, 
which is placed in the Pepsini in Townes' classification (new synonymy).

\section{Mystacagenia, new genus \\ $T y$ pe-species. $-M$. variegata, new species}

Generic characters. - Females with the general features of Ageniella, including wing venation (shown in Fig. 2); males unknown. Length of known species 5.5-8.5 mm; variously colored, with banded wings. Maxillary palpi very long, capable of reaching apex of front coxa; mentum with a few thin setae; mandibles with a basal swelling just below which there is a group of long, pale setae which overly and partially conceal the mandible; mandibles slender apically, with a small tooth on the inner margin that is strongly set off from the shaft. Labrum partially exposed, with a deep median notch; clypeus about as wide as lower face; malar space well developed, at least half as long as width of mandibles at their base; antennae unusually slender (Figs. I, 3). Propodeum sloping evenly, its surface smooth and devoid of setae; legs devoid of setae except for very minute ones on the tibiae and tarsi; claws dentate. First abdominal segment hourglass shaped at extreme base; last segment bearing a number of setae, without a smooth pygidial area.

\section{Key to species (females)}

I. Front of head, including mouthparts, white in color; vertex bearing several strong, curved, white setae just behind the ocelli (Fig. 3); hind wings with a subapical band

albiceps, new species

Front of head largely ferruginous; vertex without prominent setae; hind wings hyaline

2

2. Abdomen largely fuscous except basal and apical segments white; fore wings hyaline, with a strong band below the stigma and a narrow band over the transverse median vein; length of fore wing $5 \mathrm{~mm}$ bellula, new species

Abdomen with all segments irregularly blotched with brown and white; fore wings opaque whitish, crossed by three brown bands, the outer two connected above; length of fore wing $7.5 \mathrm{~mm}$ variegata, new species

Mystacagenia variegata, new species

Holotype, - + , Nova Teutonia, Santa Catarina, Brazil, 2 I Jan. 1956 (Fritz Plaumann) [Coll. H. K. Townes, Ann Arbor, Mich.]. 

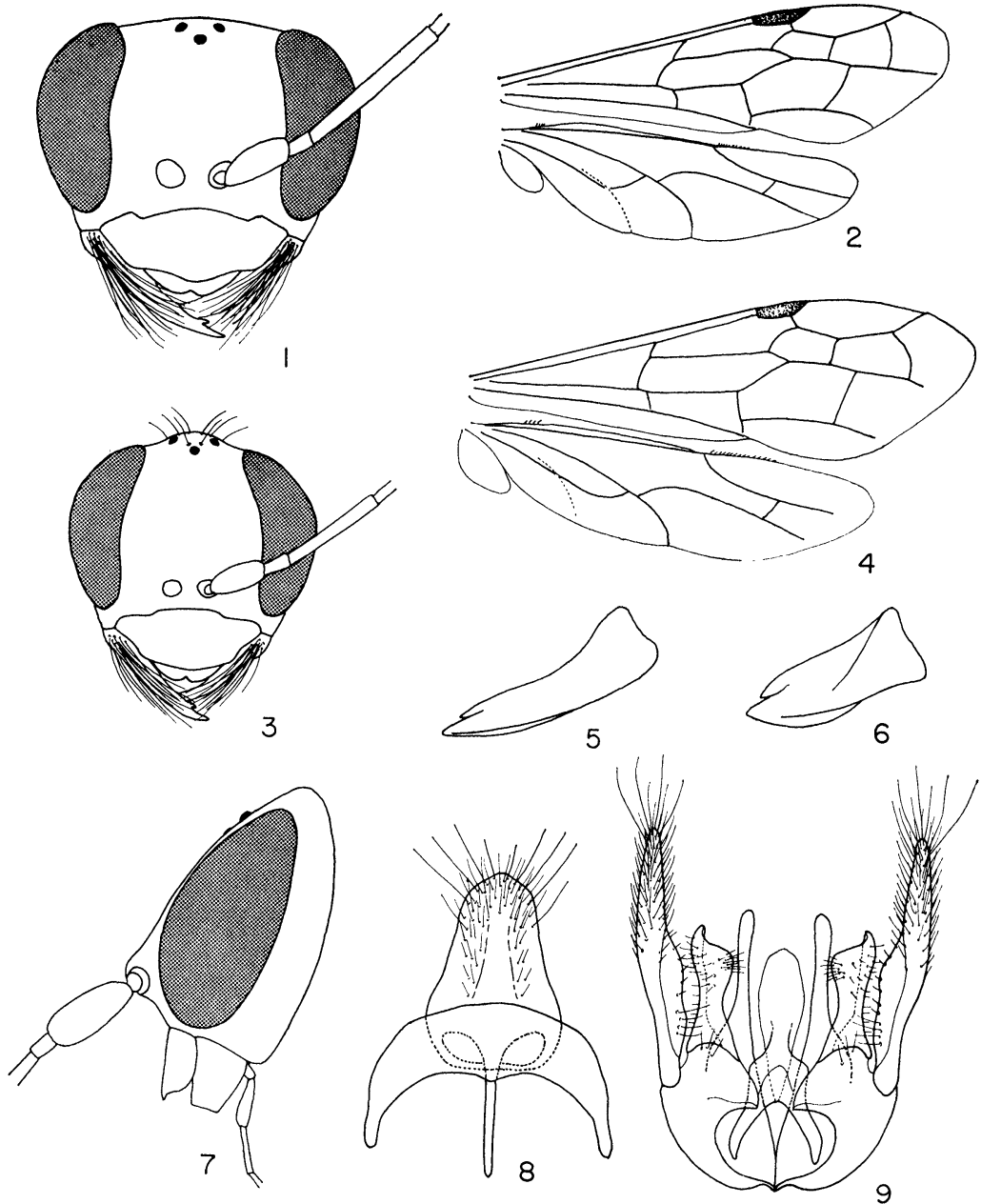

Fig. 1. Anterior view of head of Mystacagenia variegata n. sp., type + . Fig. 2. Wings of same specimen, color pattern not shown. Fig. 3. Anterior view of head of $M$. albiceps n. sp., type + . Fig. 4. Wings of Dimorphagenia naumanni n. sp., allotype + . Fig. 5. Mandible of same specimen. Fig 6. Mandible of Ageniella (Cyrtagenia) innuba n. sp., type + . Fig. 7. Lateral view of head of same specimen. Fig. 8. Subgenital plate of $D i$ morphagenia naumanni n. sp., type $\hat{o}$. Fig. 9. Genitalia of same specimen, ventral aspect. 
Description. - Length $8.4 \mathrm{~mm}$; fore wing $7.4 \mathrm{~mm}$. Head light rufous, with a pair of black spots on upper front; front and temples with a reticulate pattern of white; malar space, mandibles, and labrum mostly white; thoracic dorsum mainly light rufous, sides with broad streaks of light rufous and white, also some black on posterior parts of mesopleura and metapleura; propodeum white, with a pair of broad, longitudinal black bands; abdomen mainly whitish or somewhat cream in color, tergite I with a small amount of black laterobasally and medioapically, tergites 2-5 with much black basally, tergite 6 mostly pale; venter mostly pale, but all pale markings of abdomen irregularly tinged with brown; antennae stramineous and partially infuscated on basal 0.3 , again at basal vein, this band connected through the first submarginal cell with another band partially crossing the wing at the second submarginal; hind wings hyaline. Body with pale, inconspicuous pubescence; erect setae absent except on clypeus, mouthparts, venter and apex of abdomen.

Clypeus $3 \times$ as wide as high, its apical margin sinuate, with a broadly rounded median lobe; front broad, middle interocular distance .6o $\times$ head width; upper interocular distance $.70 \times$ lower interocular distance; vertex very weakly arched between eye tops, subcarinate behind ocelli; postocellar line: ocello-ocular line $=4: 5$; antennae very slender, third segment $6.6 \times$ as long as its apical width, I.2 $\times$ upper interocular distance (Fig. I). Pronotum rather flat dorsally, its posterior margin broadly angulate; postnotum widened at the midline; wing venation shown in Fig. 2.

\section{Mystacagenia bellula, new species}

Holotype. - + , Avispas, $30 \mathrm{mi}$. from Marcapata, Cusco, Peru, I-I 5 Oct. 1962 (Luis Peña) [Coll H. K. Townes, Ann Arbor, Mich.].

Description. - Length $6.2 \mathrm{~mm}$; fore wing $4.7 \mathrm{~mm}$. Head testaceous to somewhat orange, with small dark blotches at center. of inner eye margins and a larger dark blotch in front of anterior ocellus; temples, malar space, and area below antennal sockets more or less white; mandibles, labrum, and palpi white; thorax and propodeum rufous except propleura and anterior corners of pronotum white; abdomen dark brown except all of segments $I$ and 6 and much of sternite 5 contrastingly white; scape white, flagellum white on basal half, testaceous on apical half, streaked with fuscous on lower surface throughout; legs white, with a complex pattern of dark brown and a small amount of rufous at base of middle and hind 
coxae. Wings clear hyaline, fore wing with a brown band over transverse median vein (weakly extended along basal vein) and a much broader brown band nearly crossing wing at stigma. Body pubescence very fine and inconspicuous; body with scarcely any erect hairs except for those on mandibles, a few on clypeus, and some thin ones on apex and venter of abdomen.

Clypeus $2.7 \times$ as wide as high, shaped as in the preceding species; front less broad than in variegata, middle interocular distance $.55 \times$ head width; upper interocular distance $.73 \times$ lower interocular distance; vertex very weakly arched above eye tops; postocellar line: ocello-ocular line $=6: 7$; antennae very slender, third segment $6 \times$ as long as its apical width, I.2 $\times$ upper interocular distance. Pronotal disc rather flat, very short, posterior margin broadly angulate; metanotum angularly projecting backward medially; midline of propodeum weakly impressed; wing venation differing from that of variegata in no important details.

\section{Mystacagenia albiceps, new species}

Holotypc. - $q$, Avispas, $30 \mathrm{mi}$. from Marcapata, Cusco, Peru, I-I 5 Oct. I962 (Luis Peña) [Coll. H. K. Townes, Ann Arbor, Mich.].

Description. - Length $5.6 \mathrm{~mm}$; fore wing $4.5 \mathrm{~mm}$. Head and mouthparts entirely white except vertex and occiput blotched with testaceous; thorax and propodeum predominantly rufotestaceous, blotched with fuscous across much of pronotal disc, center of mesoscutum, basc and apex of scutellum, along pleural sutures, and over most of venter; abdomen rufotestaceous, blotched with fuscous on sides of tergites I-4, tergites 2 and 3 also with small lateral white spots; scape mostly white, flagellum brown, darkened toward apex; legs mostly rufotestaceous, coxae blotched with fuscous, apices of femora and most of tibiae blotched with fuscous and annulated with white. Wings hyaline except hind wing with a preapical brown band, apex clear; fore wing brownish at base, across basal and transverse median veins, and in a broad band below stigma, the last band extended along radial vein. Pubescence delicate, inconspicuous; clypeus with several white setae in addition to the tufts on the mandibles, ocellar area also with several strong, curved, white setae; scutellum and apex and venter of abdomen with sparse, weaker setae.

Clypeus 2.4 $X$ as wide as high, apical margin weakly convex; head subcircular in anterior view; middle interocular distance $.60 \times$ head width; upper interocular distance $.68 \times$ lower interocular dis- 
tance; vertex strongly elevated above eye tops, especially at ocellar triangle; postocellar line: ocello-ocular line $=2: 1$; third antennal segment $7.5 \times$ as long as its apical width, I.I $\times$ upper interocular distance (Fig. 3). Pronotum short, disc sloping and with no flat dorsal surface; postnotum transverse, not projecting backward medially. Wing venation similar to that of variegata but stigma unusually wide, third submarginal cell smaller, only $\mathrm{I} .5 \times$ as wide as high, removed from wingtip by twice its own width.

\section{Dimorphagenia, new genus}

Type-species. - D. naumanni, new species.

Generic characters. - With the general features of the Auplopodini, including the wing venation (shown in Fig. 4) and the form of the first abdominal segment; length 7-10 $\mathrm{mm}$; wings unbanded, lightly tinged with brown. Female: maxillary palpi of moderate length; mentum with a number of strong setae arising near base and directed forward, much as in Auplopus; mandibles slender, with scattered, strong bristles (Fig. 5) ; labrum wholly concealed; clypeus not extending under lower margins of eyes; malar space about one third as long as width of mandibles at their base; temples well developed, not strongly receding, nearly as wide as eyes; vertex extended well above eye tops; ocellar triangle located well before vertex crest; propodeum with smooth contours, slope low and even; legs relatively smooth, but middle and hind tibiae bearing numerous spines of moderate length; claws dentate, tooth arising rather close to outer ray; apical tergite with a flat pygidial area which is devoid of setae but is minutely punctate and shagreened. Male (Fig. IO) : head remarkably enlarged, much wider than thorax, vertex far above eye tops and ocelli, temples much wider than eyes; malar space about half as long as width of mandibles at their base; antennae elongate, capable of reaching middle of abdomen; tarsal claws and spines of tibiae as in female; first abdominal segment much expanded from the base, but with no evidence of a lateral seam. Subgenital plate tongueshaped, midline only weakly elevated (Fig. 8); genitalia with the basal hooklets absent, parameres elongate, digiti broad and abruptly truncate apically (Fig. 9).

Remarks. - This genus is most closely related to Auplopus, differing in the less strongly petiolate abdomen (especially in the male), the less well defined pygidial area, presence of a short malar space, broad clypeus with a slightly concave apical margin, and several other features. The male genitalia differ in no important details from those of Auplopus. 


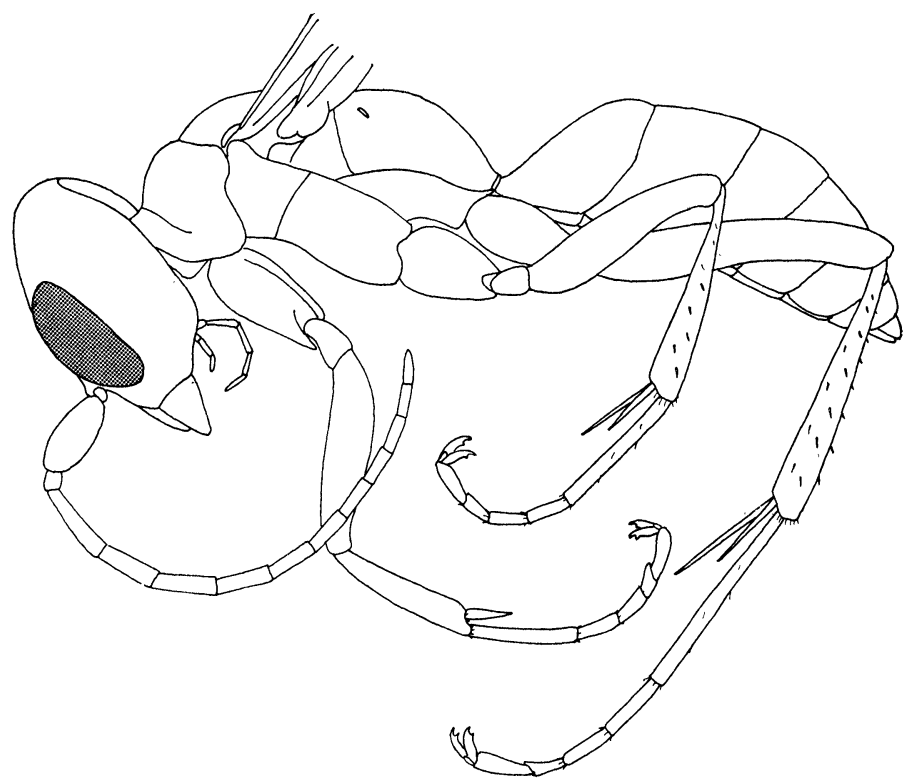

Fig. 10. Dimorphagenia naumanni, type ô, wings omitted.

Dimorphagenia naumanni, new species

Holotype. - $\sigma^{x}$, Limoncoche, Prov. Napo, Ecuador $\left(\mathrm{Oo}^{\circ} 24^{\prime} \mathrm{S}\right.$, $76^{\circ} 36^{\prime} \mathrm{W}$ ) 7 May I97 I (Martin G. Naumann, nest 2048) [Mus. Comp. Zool., no. 32 I05].

Description of male type. - Length $7 \mathrm{~mm}$; fore wing $6 \mathrm{~mm}$. Entire body testaceous except center of front and (to a lesser degree) vertex blotched with medium brown; legs wholly testaceous; antennae testaceous darkened to medium brown beyond basal third, flagellar segments narrowly ringed with fuscous apically. Wings very lightly tinged with brown; stigma testaceous. Pubescence pale, inconspicuous. Body largely devoid of erect setae except for strong bristles on clypeus and mandibles, scattered setae on front, vertex, and thoracic dorsum (but not propodeum), and numerous short setae toward apex of abdomen.

Clypeus $2.8 \times$ as wide as high, apical margin weakly concave; middle interocular distance $.68 \times$ head width, $\mathrm{I} .4 \times$ eye height; upper and lower interocular distances subequal; postocellar line: 
ocello-ocular line $=2: 5$; in lateral view, distance from eye tops to vertex crest $.7 \times$ eye height, temples about $1.5 \times$ eye width; third antennal segment $4.3 \times$ as long as wide, equal to slightly less than half upper interocular distance. Maximum width of thorax only .7 that of head; pronotum weakly expanded dorsally, its midline depressed. Wing venation as in female; terminalia as figured (Figs. 8, 9); lateral view of body shown in Fig. Io.

Allotype. - 9 , same data as type except dated 3 July I97 I [Mus. Comp. Zool.].

Description of female allotype. - Length Io $\mathrm{mm}$; fore wing $8 \mathrm{~mm}$. Head, thorax, and propodeum dark brown, somewhat shining; abdomen rufous except base of first segment black; antennae dark brown; coxae, trochanters, and tarsi dark brown, femora and tibiae rufous. Wings tinged with yellowish brown; stigma light brown. Pubescence cinereous to light brown, rather conspicuous on coxae, pleura, and propodeum. Body with fairly numerous pale, erect hairs, including some on thoracic dorsum and pleura, propodeum, coxae, and especially the abdominal venter; hind femora with scattered short hairs.

Clypeus 2.5 $X$ as wide as high, its apical margin weakly concave; middle interocular distance $.63 \times$ head width, I.I $\times$ eye height; upper interocular distance very slightly exceeding lower interocular distance; vertex broadly rounded off well above eye tops, distance from posterior ocelli to top of vertex exceeding postocellar line; postocellar line: ocello-ocular line $=2: 5$; temples strong, although roundly contracted from behind the eyes, in lateral view not quite as wide as eyes; antennae not especially elongate, third segment only about half the upper interocular distance. Maximum width of thorax only slightly less than that of head; features of pronotum and postnotum as described for male; wing venation as in Fig. 4; legs and abdomen as described under generic heading.

Paratypes. -2 우, same data as allotype [U.S. Nat. Mus., British Mus.].

Variation. - Both paratypes are slightly smaller than the allotype (fore wing $7.3,7.5 \mathrm{~mm}$ ) but there are no differences worthy of note.

Remarks. - Despite the great difference in head structure in the two sexes, there is close agreement in all other essential features, and there can be no question that these are male and female of one species. This is the only case known to me in the Pompilidae in which sexual dimorphism involves a major difference in head size. In this connection the following notes provided by Martin G. 
Naumann may be of interest (his nest no. 2048; see type designation for locality).

This was a nest of Stelopolybia sp., a social vespid that typically nests in cavities. In this case the nest occupied several cavities inside a large carton ant nest (Azteca $s p$.) attached to a tree trunk, $2 \mathrm{~m}$ above the ground. On May 7, a wasp was seen walking about on the surface of the ant nest. It was captured and proved to be a male pompilid (the type of this species). On June $2 \mathrm{I}$ both wasp and ant nest were heavily damaged by children, but on July 3 both wasps and ants were still active, and the nest was harvested by chloroforming it and catching the contents in a sac. The three female pompilids were found among the vespids, the ants, and the rubble.

Structure of the females suggests strongly that they build mud cells: this is the usual function of stiff bristles on the labium and a smooth pygidial plate. In this instance it seems probable that they were utilizing a part of one of the cavities inside the ant nest and being tolerated by the ants and the vespids. I suggest that the large head of the male may enable it to pass as a worker Azteca ant. These ants are polymorphic, and the larger workers commonly are macrocephalic. In this instance the workers were considerably smaller than the male Dimorphagenia, but they were of a similar pale color and the larger workers decidedly macrocephalic. Presumably macrocephaly does not occur in the female sex because it would render them unable to perform their usual hunting and nest-building activities. Macrocephaly in the male suggests that the male is more than a passive inhabitant of the nest; perhaps the presence of several such males inhibits attacks by ants and social wasps. One can only hope that the relationships of these insects can some day be worked out in detail.

\section{Genus Ageniella Banks \\ Cyrtagenia, new subgenus}

\section{Type-species. - Ameragenia fallax Arlé.}

Subgeneric characters. - Females with the general features of Ageniella s. str. except as follows (males unknown). Mandibles unusually broad, with a small tooth located close to the apex (Fig. 6); clypeus with rather sharp anterolateral corners and with a median, apical angulation; front, in lateral view, either abruptly subangulate a short distance above the antennal sockets, then flat to the vertex crest, or flattened all the way from the antennal sockets to the vertex (Fig. 7), in either case with a median prominence just above the 
sockets. Pronotum short, with a somewhat flattened dorsal part; propodeum with smooth contours, without erect setae or with a very few setae on each side; legs relatively smooth, but middle and hind tibiae with several rows of very small spines; brush on inner side of hind tibia continuous to apex. Third submarginal cell receiving second. recurrent vein .4 the distance from the base; anal vein of hind wing reaching media well before cubital fork. Known species with the wings unbanded, the antennae dark but with a white annulus near the middle.

Remarks. - Arnold (1934) described a genus from Africa in which the female has the front more or less angulate in profile, Arpactomorpha. However, in this genus the angulate portion has a median groove, and below the angulation there is an oblique impression on each side of the face. Furthermore, in Arpactomorpha the mentum has a beard composed of four or five long bristles arising from the base, whereas in Cyrtagenia there are only a few weak setae arising along the length of the mentum, as usual in Ageniella. I doubt if there is any close relationship between these two groups.

\section{Key to species (Females)}

Angulation of front well above antennal sockets; some of the abdominal tergites with lateral white spots;-pubescence fine and relatively inconspicuous fallax (Arlé)

Front forming a nearly flat, oblique slope from the antennal sockets to the vertex (Fig. 7); abdomen without white spots; pubescence unusually coarse and hoary innuba, new species

\section{Ageniella (Cyrtagenia)fallax (Arlé) new combination}

Ameragenia fallax Arlé 1947, pp. 426-428, figs. 23-25.

Arlé's description and figures are excellent, and there seems no need to redescribe the species at this time. Arlé had a single female, from near Rio de Janeiro. The species appears to be widely distributed, as I have seen females from Teresopolis and Nova Teutonia, Brazil; Oran and Tucumán, Argentina; and Avispas, near Marcapata, Peru. These females are exceedingly variable in color. All have a pale annulation on the antennae and at least small spots on the sides of the abdomen, but the other maculations described by Arlé may be much reduced or even absent. At the other extreme, the specimen from Peru is exceedingly ornate, having ivory spots over much of the head and thorax, as well as a median stripe on the 
propodeum and lateral stripes on the first tergite. It is possible that more than one species is involved, but on the basis of presently available material I am inclined to think not.

\section{Ageniella (Cyrtagenia) innuba, new species}

Holotype. - + , Nova Teutonia, Santa Catarina, Brazil, Jan. 1966 (Fritz Plaumann) [Mus. Comp. Zool., no. 32 Io6].

Description of female type. - Length $9 \mathrm{~mm}$; fore wing $8.3 \mathrm{~mm}$. Head black except marked with white as follows: apical .8 of clypeus; narrow inner orbits, with extensions toward antennal sockets; a median streak before anterior ocellus; small spots at eye tops; lower outer orbits and malar space; mandibles white basally, then testaceous, with dark tips; palpi testaceous; basal 5 antennal segments black (except scape with a small white spot), next three segments mainly white, remainder dark brown above, light brown below. Thorax and propodeum black; abdomen rufous except first segment black basally; legs rufotestaceous except coxae, trochanters, and femora partially infuscated; tarsi in part whitish. Wings hyaline, veins and stigma dark brown. Pubescence coarse, cinereous, giving the body a somewhat hoary appearance; propodeum with a ferv short erect hairs on each side and abdominal venter and apical tergite setose, but body otherwise without erect hairs.

Clypeus $2.6 \times$ as wide as high; malar space $.2 \times$ width of mandibles at their base; middle interocular distance $.59 \times$ head width; upper interocular distance $.95 \times$ lower interocular distance; postocellar line: ocello-ocular line $=2: 3$; vertex rather sharp, distance from posterior ocelli to crest about equal to postocellar line. Front rather flat from vertex crest to antennae, which arise from a protuberance, as shown in Fig. 7; third antennal segment equal to $.72 \times$ upper interocular distance. Hind tibia with a faint longitudinal impression between the two uppermost rows of small spines.

Paratypes. - BRAZIL: I $\%$, same data as type but collected January I965 [U.S. Nat. Mus.] ; I \%, Teresopolis, I I March 1966 (H. \& M. Townes) [Coll. H. K. Townes].

Variation. - Both paratypes have a small white spot on each posterior pronotal lobe. The abdomen of the Teresopolis specimen is dusky ferruginous, the legs darker than in the type. The topotypic paratype is slightly smaller than the type (fore wing $8 \mathrm{~mm}$ ) and has a white spot on the third antennal segment as well as a large one on the scape. 
Key to Neotropical genera of Auplopodini (Females)

(Modified from Banks, I946, and Townes, 1957)

1. Apex of front tibia on outer side with a strongly differentiated, curved, hooklike spine; clypeus large, extending well beneath bottoms of eyes

2

Apex of front tibia without a strong, curved spine that is well differentiated from the other spines

3

2. Last segment of middle and hind tarsi spined beneath; lower part of mesopleurum with a projection; clypeus strongly emarginate

Phanochilus Banks

Last segment of all tarsi smooth beneath; mesopleurum without a prominence; clypeus truncate

Priocnemella Banks

3. Mandibles with a basal tuft of long, pale setae which cover much of the mandibles; malar space at least half as long as width of mandibles at their base (Figs. I, 3)

Mystacagenia, new genus

Mandibles without such modification, simple and with scattered setae; malar space less than half as long as width of mandibles at their base, often nearly absent

4. Apical tergite covered with bristles and without a differentiated pygidial area; mentum with or without a few thin setae scattered along its length

A geniella Banks

Apical tergite with a median area which is devoid of setae and more or less smooth, often polished; mentum with a group of stout setae arising near the base and directed forward ....... 5

5. Malar space about one third as long as width of mandibles at their base; temples prominent, nearly as wide as eyes; tooth of claws quite close to outer ray (males macrocephalic, Fig. IO)

Dimorphagenia, new genus

Malar space small or absent, mandibles and lower eye margins nearly in contact; temples narrow, receding; tooth of claws well separated from outer ray Auplopus Spinola

Key to Neotropical subgenera of Ageniella (Females)

I. Propodeum with an abundance of erect hair 2

Propodeum without hair or with a few inconspicuous hairs on the sides

2. Mentum at most with a few short, inconspicuous setae; mostly small species, under $\mathrm{I} 4 \mathrm{~mm}$ Ameragenia Banks Mentum with a number of rather long setae; larger species, mostly over I $5 \mathrm{~mm}$ 
3. Hind tibiae serrate in profile, also quite strongly spinose; most species with a prominence on lower part of mesopleurum Alasagenia Banks

Hind tibiae smooth, non-serrate, and with only small spines; mesopleurum without a prominence Lissagenia Banks

4. Front, in lateral view, somewhat angulate (either at the antennal sockets or between sockets and ocelli), above the angulation quite flat; mandibles unusually broad, the tooth small (Fig. 6)

Cyrtagenia, new subgenus

Front, in lateral view, more or less gently rounded; mandibles not modified as above

5. Hind tibia not at all serrate, smooth or with rows of very small spines Ageniella Banks

Hind tibia serrate in profile

6. Brush on inner side of hind tibia with a subapical interruption; pronotum somewhat elongate Nemagenia Banks Brush on inner side of hind tibia without a subapical interruption Priophanes Banks

\section{REFERENCES}

ARLÉ, R.

1947. Nouvelles espèces de Pompilidae du Brésil (Hymenoptera). Rev. de Ent., 18 : 416-428.

ARNOLD, G.

1934. Psammocharidae of the Ethiopian region. Part 2. Ann. Transvaal Mus., 15 : 283-399.

BANKs, N.

1946. Studies of South American Psammocharidae. Part 1. Bull. Mus.

Evans, H. E. Comp. Zool., 96: 311-525.

1966. A revision of the Mexican and Central American spider wasps of the subfamily Pompilinae (Hymenoptera: Pompilidae). Mem.

HaUPT, H. Amer. Ent. Soc., no. 20, 439 pp.

1959. Elemente einer systematischen Aufteilung der Macromerinae m. (Hymenoptera-Sphecoidea). Nova Acta Leopoldina, (9) 21, no. Townes, $\mathrm{H}$. 141, 74 pp.

1957. Nearctic wasps of the subfamilies Pepsinae and Ceropalinae. Bull. U.S. Nat. Mus., no. 209, 286 pp. 

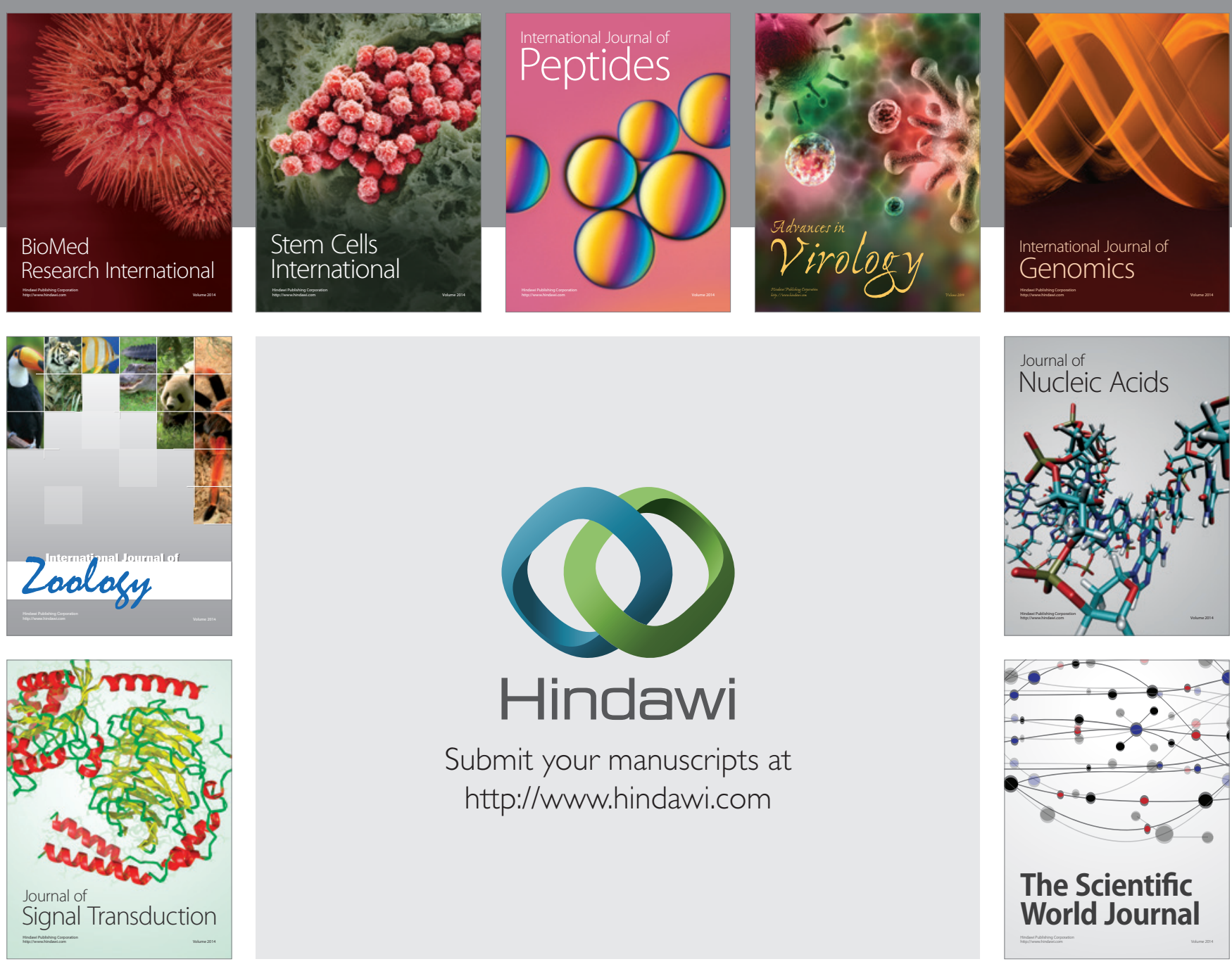

Submit your manuscripts at

http://www.hindawi.com
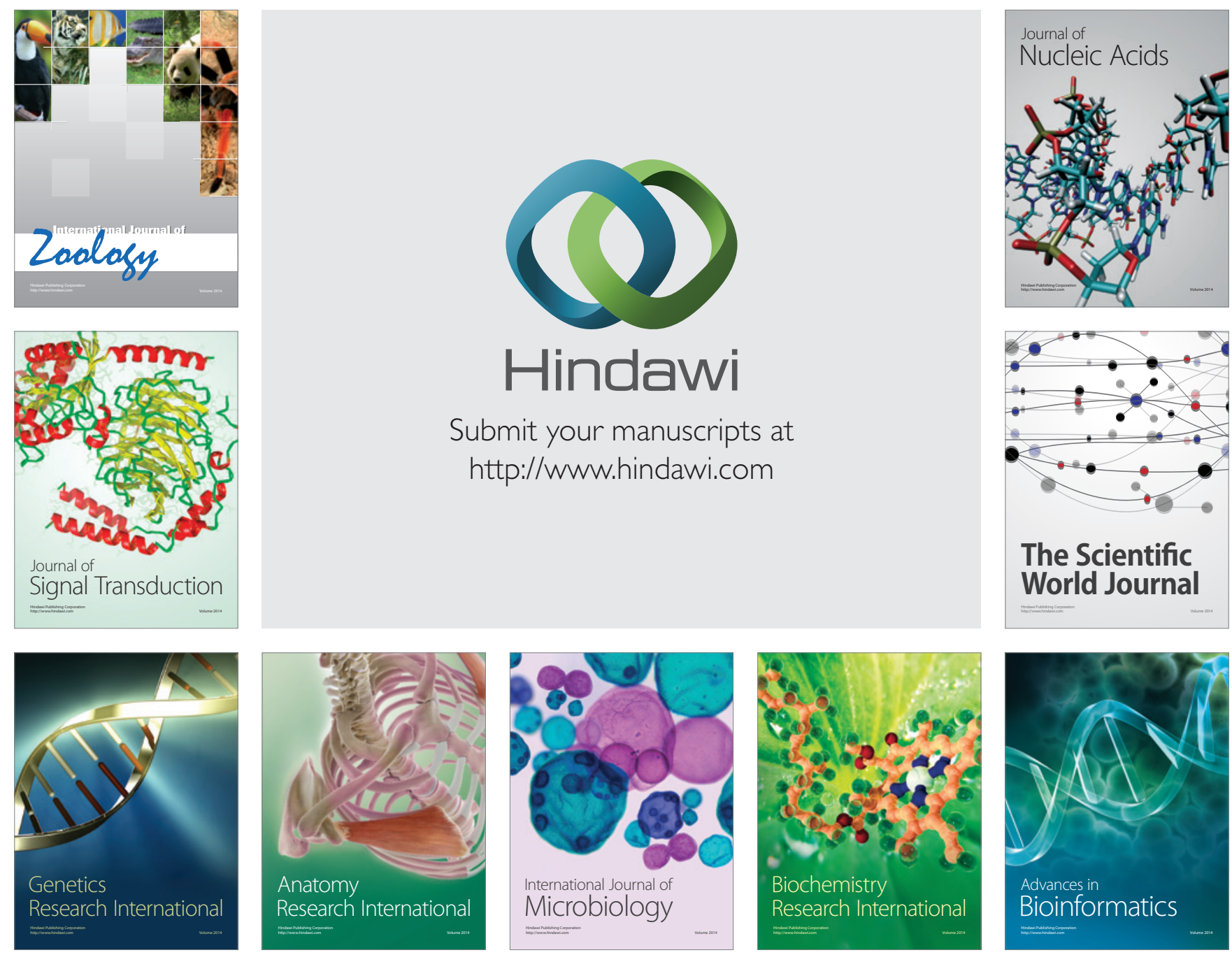

The Scientific World Journal
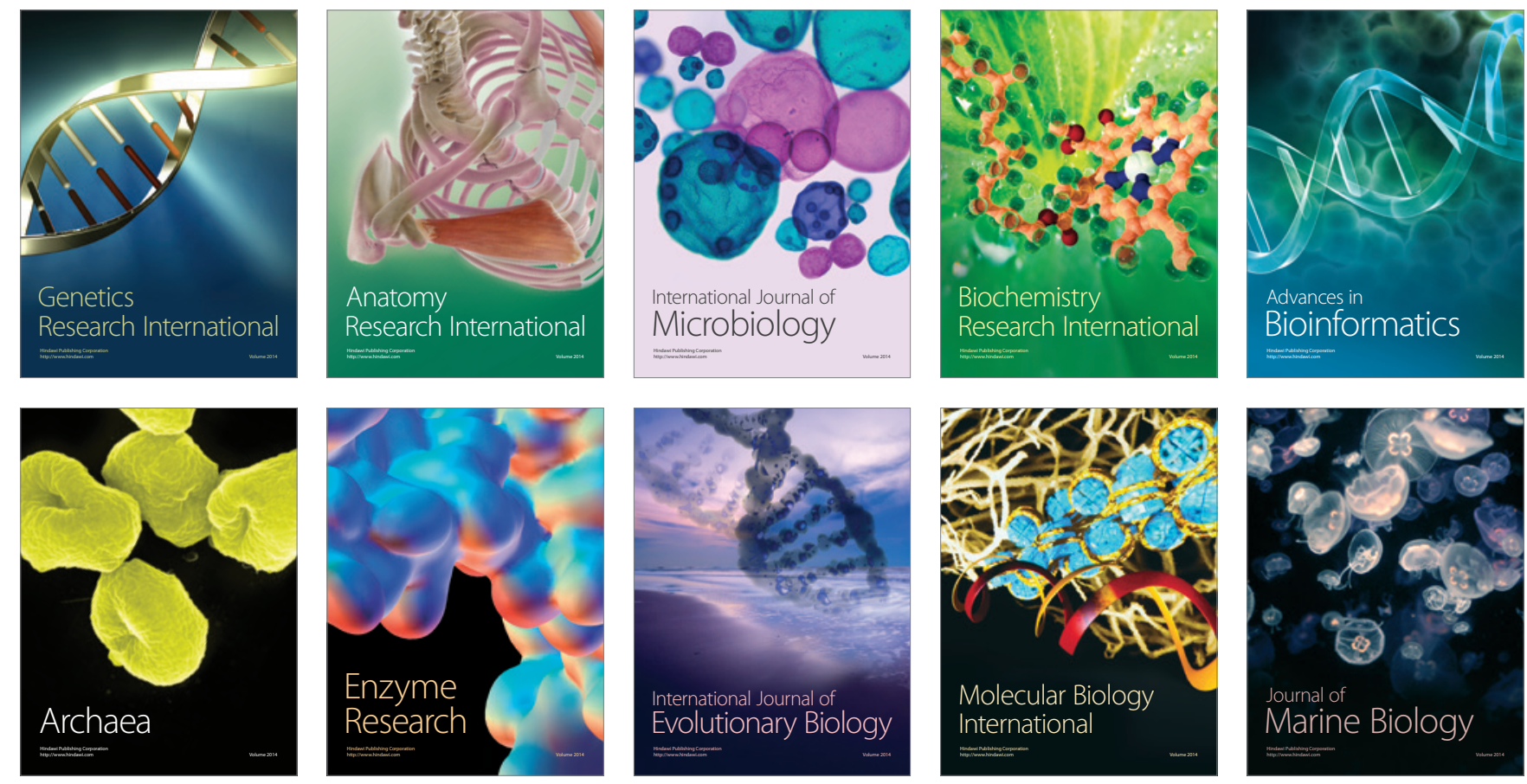